\title{
Transference in vitro of the resistance to the antimicrobials between Escherichia coli, Lactobacillus spp. and Salmonella enteritidis isolated from chickens
}

\author{
[Transferência in vitro da resistência aos antimicrobianos entre Escherichia coli, Lactobacillus.spp e \\ Salmonella enteritidis isoladas de frangos] \\ A.S. Okamoto, R.L. Andreatti Filho, T.S. Rocha, E.L. Milbradt \\ Laboratório de Ornitopatologia - Departamento de Clínica Veterinária - FMVZ - UNESP \\ Caixa Postal 560 \\ 18618-000 - Botucatu, São Paulo
}

\begin{abstract}
The objective of this work was to verify the possibility of transference of resistance to the antimicrobials between bacteria that are in the present normal microbiota of chickens and Salmonella Enteritidis. Samples of Lactobacillus spp. (L. spp.), Salmonella Enteritidis (SE) and Escherichia coli (E. coli) previously isolated from chickens, selected after the test of sensitivity antimicrobial in vitro according the standard method (National Committee for Clinical Laboratory Standards) utilizing those with resistance and sensibility to the antimicrobials inductors, named donor and receptor bacteria, respectively were used. Antimicrobials inductors were utilized to stimulate the transference of resistance to the antimicrobials between the bacteria. The possibility of transference was verified from the E. coli resistant to the SE and $L$. spp. Transference of a sample of $L$. spp resistant to the antimicrobials inductors to the SE was also verified. It was only possible to verify the transference of the resistance to the antimicrobials inductor when the donor bacteria was the E. coli and the bacteria receptor was SE. In the present study we conclude that the transference of resistance to the antimicrobials between bacteria is possible, however, not all bacteria participate in that trial, not transmitting and neither acquiring this resistance.
\end{abstract}

Keywords: transfer, resistance to antimicrobials, Escherichia coli, Salmonella Enteritidis, Lactobacillus

\section{RESUMO}

O objetivo deste trabalho foi verificar a possibilidade de transferência de resistência aos antimicrobianos entre bactérias normais da microbiota de frangos e Salmonella Enteritidis. Utilizamos amostras de Lactobacillus spp. (L. spp.), Salmonella Enteritidis (SE) e Escherichia coli (E. coli) previamente isolados de frangos, selecionados após prova de sensibilidade antimicrobiana in vitro conforme metodologia padrão (Comitê Nacional para Padrões Clínicos de Laboratório). Utilizamos aqueles com resistência e sensibilidade aos antimicrobianos indutores, chamados de bactérias doadoras e receptoras, respectivamente. Os antimicrobianos indutores foram utilizados para estimular a transferência de resistência aos antimicrobianos entre as bactérias. A possibilidade de transferência foi verificada da E. coli resistente para a SE e L. spp. Também foi verificada a transferência de uma amostra de L. spp resistente aos antimicrobianos indutores para a SE. Só foi possível verificar a transferência da resistência aos antimicrobianos indutores quando a bactéria doadora foi a E. coli e a bactéria receptora foi a SE. No presente estudo concluímos que a transferência de resistência aos antimicrobianos entre bactérias é possível, mas nem todas as bactérias participam desse evento, não transmitindo e nem adquirindo esta resistência.

Palavras-chave: transferência, resistência aos antimicrobianos, E. coli,, Salmonella Enteritidis, Lactobacillus

Recebido em 7 de março de 2011

Aceito em 12 de julho de 2011

E-mail:sakai@fmvz.unesp.br 


\section{INTRODUCTION}

The Enterobacteriaceae family includes genera that inhabit the intestinal tract of humans and other animals, as well as non-pathogenic (commensal) and pathogenic species (Howard et al., 1987).This gastrointestinal microbiota is considered the first biological barrier against pathogenic bacteria (Ouwehand et al., 2002). These microorganisms colonize in high population levels (higher than $10^{7}$ viable cells per gram of contents) in the gastrointestinal tract of broiler chickens (Zhu and Joerger, 2003) and they have been scientifically shown to influence the composition and activity of the intestinal microbiota and have beneficial effects in the host by preventing or reducing the duration of some gastrointestinal infections (Ouwehand et al., 2002). Many species belonging to this family, which are present in the intestinal tract, are frequently exposed to different antimicrobials, creating the potential to disseminate genes of resistance to antimicrobials (Goldstein et al., 2001).

Lactic acid bacteria (LAB), staphylococci, and micrococci, which are always dominant in fermented products, have been found to carry antibiotic resistance determinants (Martín et al., 2006). More recent investigations have examined the involvement of nonpathogenic $\mathrm{LAB}$ in spreading resistance genes in the environment and their possible role as resistance gene reservoirs (Ammor et al., 2007). Genes conferring resistance to antimicrobials such as tetracycline, erythromycin, streptomycin, chloramphenicol, and vancomycin have been found in LAB isolated from foods (Perreten et al., 1997).

The dissemination of resistance elements from $\mathrm{LAB}$ to pathogens in the environment is a major risk factor and one that may adversely impact public health. Indirect evidence shows that resistance elements can transfer between LAB and pathogenic strains (Courvalin, 1994). Studies on microbial resistance to antibiotics mainly focus on clinically relevant bacterial species, but in recent years more attention has been given to nonclinical isolates because it is known that antibiotic resistance is also widespread among such isolates (Ammor et al., 2007).
Among nonclinical isolates, commensal and ubiquitous bacteria represent a reservoir of antibiotic resistance genes with the potential to be transferred to human, animal, and microbial pathogens (Saylers et al., 2004).

According to Okamoto et al. (2009) 80\% of the samples of Salmonella Enteritidis isolated from chickens submitted to the antibiogram were resistant to over three antimicrobials, being that among those samples not one presented the gene of resistance to the antimicrobials researched (Integron Class 1), demonstrating this way that the acquisition of resistance to the antimicrobials by the bacteria can occur also through other factors or other genes involved in this mechanism.

The objective of the present work was to verify the possibility of transference of resistance to the antimicrobials between present bacteria in the normal microbiota of chickens and Salmonella Enteritidis.

\section{MATERIAL AND METHODS}

All the bacterial samples utilized in this experiment were isolated from chickens (Gallus gallus) and identified in the Laboratory of Avian Pathology. Mutant SE samples resistant to nalidixic acid and rifampicin (Nal/Rif) were utilized to facilitate after bacterium enumeration, reactivating in tubes containing $3 \mathrm{~mL}$ brain heart infusion (BHI) and incubated under aerobiosis at $37^{\circ} \mathrm{C}$ for 24 hours. They were then seeded onto Petri dishes containing brilliant green agar (BGA) Nal/Rif at $100 \mu \mathrm{L} / \mathrm{mL}$.

The samples of non patogenic Escherichia coli were utilized in this experiment with bacteria donor of resistance to antimicrobials. The samples of Lactobacillus spp. were submitted to the corroboration of genus through the molecular biology through the Polymerase Chain Reaction (PCR) technique before the beginning of the experiment.

The extraction of the DNA from the samples of Lactobacillus spp. was done utilizing initially QIAamp DNA Stool Mini Kit (Quiagen) and subsequently with the QIAamp DNA blood Mini Kit (Quiagen) according to manufacturer instructions. For PCR the pair of primers: LbLMA1-rev (5'-CTC AAA ACT AAA CAA 
AGT TTC -3') and R16-1 (5'-CTT GTA CAC ACC GCC CGT CA-3') was utilized, obtaining a product of approximately 250 pairs of bases.

Each reaction of $25 \mu \mathrm{L}$ had $1 \mu \mathrm{L}$ of each primer (10 pmol of each), $12.5 \mu \mathrm{L}$ of Go taq Green Master Mix (Promega), $5.5 \mu \mathrm{L}$ of water and $5 \mu \mathrm{L}$ of the DNA sample $(1 \mu \mathrm{g})$. The amplification program carried out was $95^{\circ} \mathrm{C}$ during 5 minutes, followed by 20 cycles of: $95^{\circ} \mathrm{C}$ during 30 seconds, $55^{\circ} \mathrm{C}$ during 30 seconds and $72^{\circ} \mathrm{C}$ during 30 seconds, and final stretching during 7 minutes at $72^{\circ} \mathrm{C}$. At the end of the last cycle, the products of PCR were stored at $4^{\circ} \mathrm{C}$ until they were used. The products of the PCR were submitted to the electrophoreses in agarose gel to $1.5 \%$ and visualized in UV light transiluminator after coloring with bromide of etidio for verification of the reaction and corroboration of the genus Lactobacillus.

Antibiotic susceptibility was determined semi quantitatively by disc diffusion using a modification of the agar overlay diffusion method of the National Committee for Clinical Laboratory Standards (NCCLS). MRS agar was used for susceptibility testing of Lactobacilli. Petri plates containing $15 \mathrm{~mL}$ of agar, were overlaid with $4 \mathrm{~mL}$ of soft agar seeded with $200 \mu \mathrm{L}$ of an active culture at $45^{\circ} \mathrm{C}$. This provided a moderately heavy inoculum of about $10^{7}$ viable cells per $\mathrm{mL}$ of agar overlay. Petri plates were allowed to stand at room temperature for 15 minutes prior to dispensing antibioticcontaining discs with the Oxoid MKII Disc Dispensing System (Unipath Ltd). Plates were incubated anaerobically at $37^{\circ} \mathrm{C}$ for 24 hours without prediffusion or preincubation. Inhibition zone diameters were measured using sliding calipers, and results (average of six determinations) were expressed in terms of resistance, moderate susceptibility, or susceptibility, according to interpretative standards detailed in the research done by Charteris et al. (1998).

The bacterial samples utilized in this experiment were selected after the antimicrobial sensitivity test, utilizing those with resistance and sensibility to the antimicrobials inductors, named donor (Escherichia coli and Lactobacillus spp.) and receptor (Salmonella Enteritidis) bacteria, respectively (Table 1). The antimicrobials tetracycline, ampicillin, and trimetoprim were utilized as inductors in the transference of resistance to the antimicrobials. These antimicrobials were randomly chosen among those to which the receptor was found to be sensitive and the donor to be resistant.

Table 1. Transference of antimicrobial resistance in vitro

\begin{tabular}{cl} 
Transference & \multicolumn{1}{c}{ Donor $\rightarrow$ Receiver } \\
\hline A & Escherichia coli $\rightarrow$ Salmonella Enteritidis \\
B & Escherichia coli $\rightarrow$ Lactobacillus spp. \\
C & Lactobacillus spp. $\rightarrow$ Salmonella Enteritidis \\
\hline
\end{tabular}

All the means of culture utilized (agar and broth) in the transference were specific for each bacteria, being MRS for cultivation of the Lactobacillus spp. and nutrient for cultivation of the Escherichia coli and Salmonella Enteritidis. In order to choose donor and receptor bacteria, the antibiogram test was performed prior to the beginning of the experiment to demonstrate their resistance or sensitivity to antimicrobials.

Adapting the technique utilized by Okamoto et al. (2009), inductors antimicrobials were added at the concentration of $5 \mathrm{mg} / \mathrm{mL}$ to the means of culture. Transference was initiated by separately incubating the bacteria donor and receptor in broth, respectively, at $37^{\circ} \mathrm{C}$ for 24 hours, which was subsequently diluted 100 times in broth preheated to $37^{\circ} \mathrm{C}$, and incubated for another 4 hours. Cultures were then centrifuged at 7300 rpm, and the sediment from each bacterium (donor and receptor) was homogenized with $2 \mathrm{~mL}$ PBS, seeded on agar, and incubated at $37^{\circ} \mathrm{C}$ for 24 hours. The dish was then washed with PBS and seeded on BGA or MRS agar $(100 \mathrm{mg} / \mathrm{mL})$ for Salmonella Enteritidis or Lactobacillus spp., respectively, with the aid of a platinum loop. Salmonella Enteritidis and Lactobacillus spp were submitted to a new antibiogram to verify the passage of resistance to the antimicrobials. 


\section{RESULTS AND DISCUSSION}

Some criteria of selection for potentially probiotics bacteria have been utilized. An important criterion is the standard of resistance to the antimicrobials (Coeuret et al., 2004), because known resistant bacteria to the antimicrobials should not be used as probiotics due to the possibility of transference of resistance genes to microbiota normal bacteria and to the potentially pathogenic present in gastrointestinal tract (Mathur and Singh, 2005).

The transference of resistance antimicrobial in vitro utilizing the Escherichia coli as donor bacteria was carried out successfully only when the Salmonella Enteritidis was used as receptor bacteria. This was also verified by Okamoto et al. (2009), where the transference of the gene responsible for that event was also observed.

The transference of resistance antimicrobial in vitro of a Lactobacillus spp. resistant to the antimicrobials indicative for the Salmonella Enteritidis was not possible. In the great majority of the cases, the resistance of the Lactobacillus spp. is not the transmittable one that can be a characteristic of the specie or of the genus (Salminem et al., 1998).

It is not known for sure why the Lactobacillus spp. does not acquire the resistance to the antimicrobials, as the horizontal transference of genes of resistance is very common among many bacteria of the Enterobacteriaceae family(De Champs et al., 1991).

\section{CONCLUSIONS}

The transference of resistance to the antimicrobials between bacteria is possible in vitro, however not all the bacteria participate straightly of that trial, not transmitting or acquiring that resistance. It's important to point out that in vivo the conditions are different, being possible to change the results.

\section{REFERENCES}

AMMOR, M.S.; FLOREZ A.B.; MAYO, B. Antibiotic resistance in non-enterococcal lactic acid bacteria and bifidobacteria. Food Microbiol., v.24, p.559-570, 2007.
COEURET, V.; GUEGUEN, M.; VERNOUX, J.P. Numbers and strains of lactobacilli in some probiotics products. Inter. J. Food Microbiol., v.97, p.147-156, 2004.

CHARTERIS, W.P.; KELLY, P.M.; MORELLI, L.; COLLINS, J.K. Antibiotic Susceptibility of Potentially Probiotic Lactobacillus Species. J. Food Protect., v.61, p.1636-1643, 1998.

COURVALIN, P. Transfer of antibiotic resistance genes between gram-positive and gram-negative bacteria. Antimicrob. Agents Chemother., v.38, p.1447-1451, 1994.

DE CHAMPS, C.; SIROT, C.; CHANAL, C. et al. Concomitant dissemination of three extendedspectrum $\beta$-lactamase among different Enterobacteriaceae isolated in a French hospital. J. Antimicrob. Chemother., v.27, p.441-457, 1991.

GOLDSTEIN, C.; LEE, M.D.; SANCHEZ, S. et al. Incidence of class 1 and 2 integrases in clinical and commensal bacteria from livestock, companion animals, and exotics. Antimicr. Agents Chemother., v.45, p.723-726, 2001.

HOWARD, B.J.; KLASS, II. J.; RUBIN, S.J. et al. Clinical and pathogenic microbiology. St Louis: The C. V. Mosby, 1987.

MARTÍN, B.; GARRIGA, M.; HUGAS, M. et al. Molecular, technological and safety characterization of Gram-positive catalase positive cocci from slightly fermented sausages. Int. J. Food Microbiol., v.107, p.148-58, 2006.

MATHUR, S.; SINGH, R. Antibiotic resistance in food lactic acid bacteria - a review. Intern. J. Food Microbiol., v.105, p.281-295, 2005.

OKAMOTO, A.S.; ANDREATTI FILHO, R.L.; ROCHA, T.S. et al. Detection and Transfer of Antimicrobial Resistance Gene Integron in Salmonella Enteritidis Derived from Avian Matéria. Braz. J. Poultr. Scie., v.11, p.161-167, 2009.

OUWEHAND, A.C.; SALMINEN, S.; ISOLAURI, E. Probiotics: an overview of beneficial effects. Antonie Van Leeuwenhoek, v.82, p.279-289, 2002.

PERRETEN, V.; SCHWARZ, F.; CRESTA, L. et al. Antibiotic resistance spread in food. Nature, v.389, p.801-802, 1997. 
Transference in vitro of the resistance...

SALMINEN, S.; VON WRIGHT, A.; MORELLI, L. et al. Demonstration of safety of probiotics: a review. Int. J. Food Microbiol.. v.44, p.93-106, 1998.

SAYLERS, A.A.; GUPTA, A.; WANG, Y. Human intestinal bacteria as reservoirs for antibiotic resistance genes. Trends Microbiol., v.12, p.412-416, 2004.
ZHU, X.Y.; JOERGER, R.D. Composition of microbiota in content and mucus from caeca of broiler chickens as measured by fluorescent in situ hybridization with group-specific, 16S rRNA-targeted oligonucleotides probes. Poultr. Scie., v.82, p.1242-1249, 2003. 